\title{
Kinerja Penyuluh Pertanian Dalam Masa Pandemi Covid-19 di Kabupaten Magelang
}

\section{The Performance of Agricultural Extension Workers During the Covid-19 Pandemic in Magelang Regency}

\author{
Haris Tri Wibowo ${ }^{1}$, Yoyon Haryanto ${ }^{2}$ \\ ${ }^{1}$ Politeknik Pembangunan Pertanian Yogyakarta-Magelang \\ Jl. Magelang Kopeng Km 7, Tegalrejo, Magelang \\ 2Pusat Pendidikan Pertanian, Badan PPSDMP \\ email: haristriwibowo@pertanian.go.id
}

\begin{abstract}
ABSTRAK
Penyuluh pertanian merupakan ujung tombak dalam usaha penyediaan bahan pangan pokok bagi 267 juta penduduk Indonesia. Dalam masa pandemi Covid-19, penyuluh pertanian harus bisa memastikan bahwa kegiatan pertanian di lapangan tetap berjalan. Penelitian ini bertujuan untuk mengetahui kinerja penyuluh pertanian selama masa pandemi Covid-19 dan mengetahui faktor-faktor yang mempengaruhi kinerja penyuluh pertanian selama masa pandemi Covid-19. Penelitian ini berlokasi di Kabupaten Magelang, Jawa Tengah dan dilakukan pada bulan Februari 2020 sampai dengan Maret 2020. Teknik penarikan sampel adalah Purposive Sampling dengan jumlah 19 kecamatan. Penarikan responden pada setiap kecamatan dilakukan secara accidental sampling yang berjumlah 100 orang. Data yang dikumpulkan dalam penelitian ini dianalisis dengan analisis deskriptif dan analisis model persamaan struktural dengan Partial Least Square menggunakan SEM PLS. Hasil penelitian menunjukkan bahwa kinerja penyuluh pertanian dalam pembinaan kepada petani/ poktan/ gapoktan selama masa pandemi Covid-19 ini mengalami perubahan. Perubahan terjadi pada jumlah kunjungan penyuluh pertanian ke sasaran, jumlah materi pembinaan yang diberikan, dan metode penyuluhan. Faktor yang mempengaruhi kinerja penyuluh antara lain karakteristik penyuluh (usia, tingkat pendidikan, dan banyaknya pelatihan di bidang pertanian yang diikuti) dan faktor eksternal (sarana prasarana dan kondisi lingkungan kerja).
\end{abstract}

Kata kunci: Penyuluhan pertanian, pandemi covid-19, kinerja penyuluh

\section{ABSTRACT}

Agricultural extension agents are at the forefront of efforts to provide staple food for Indonesia's 267 million people. During the Covid-19 pandemic, agricultural extension workers must be able to ensure that agricultural activities in the field 
continue. This study aims to determine the performance of agricultural extension agents during the Covid-19 pandemic and determine the factors that affect the performance of agricultural extension agents during the Covid-19 pandemic. This research is located in Magelang Regency, Central Java, and was conducted from February 2020 to March 2020. The sampling technique was purposive sampling, with a total of 19 districts. The withdrawal of respondents in each district was carried out by accidental sampling, amounting to 100 people. The data collected in this study were analyzed using descriptive analysis and structural equation modeling analysis with Partial Least Square using SEM PLS. The results showed that the performance of agricultural extension workers in coaching farmers/farmer groups during the Covid-19 pandemic had changed. Changes occurred in the number of agricultural extension visits to the target, the number of guidance materials provided, and extension methods. Factors that influence the instructor's performance include the instructor (age, level of education, and the amount of training he has attended in agriculture) and external factors (infrastructure and working conditions).

Keywords: Agricultural extension, Covid-19 pandemic, extension worker performance.

\section{PENDAHULUAN}

Sektor pertanian memiliki peranan penting dalam mendukung perekonomian nasional. Peran tersebut terutama dalam terciptanya ketahanan pangan, penyumbang produk domestik bruto, penciptaan lapangan kerja dan penanggulangan kemiskinan, penyedia bahan pangan dan bahan baku industri, sumber pendapatan masyarakat, serta penciptaan iklim yang kondusif bagi pertumbuhan sektor lainnya (Kementan 2014).

Di sisi lain, sektor ini juga dihadapkan pada tantangan besar untuk selalu berinovasi menghadapi dunia yang global. Untuk menjawab tantangan tersebut, diperlukan sumberdaya manusia pertanian yang andal, berkualitas, dan mempunyai kemampuan. Hal tersebut merupakan hal yang harus dimiliki para pelaku pembangunan pertanian. Pengembangan kualitas pelaku utama dan pelaku usaha pertanian dapat dilakukan melalui pendidikan dan penyuluhan pertanian.
Sektor pertanian telah terbukti beberapa kali menjadi benteng penyelamat perkonomian negera, terbukti pada krisis moneter 1998 lalu. Sektor pertanian mampu bertahan dan menjadi penyangga bagi sektor-sektor lain yang mengalami kemunduran. BPS (2020) merilis bahwa PDB sektor pertanian menjadi penyumbang tertinggi terhadap pertumbuhan ekonomi nasional pada Triwulan II 2020 yang mengalami penurunan 5,32 persen. Sektor ini tumbuh sebesar 2,80\% pada Triwulan II 2020. PDB pertanian tumbuh 16,24 persen pada Triwulan-II 2020. Ekspor komoditas pertanian mengalami kenaikan sebesar $9,67 \%$ jika dibandingkan dengan periode yang sama tahun sebelumnya.

Hasil kajian Hirawan et.al, (2019), menunjukkan bahwa peran petani dalam dalam rantai pasok pangan sangat penting. Di masa pandemi Covid-19, terjadi banyak perubahan. Hampir seluruh negara di dunia berusaha untuk memenuhi kebutuhan pangan domestiknya sendiri karena jalur perdagangan internasional terganggu 
semenjak wabah Covid-19 mulai menyebar. Produksi dalam negeri menjadi tumpuan utama bagi setiap negara saat ini, termasuk Indonesia. Fasilitas produksi, seperti mesin dan peralatan pertanian, subsidi pupuk dan benih, serta fasilitas pendukung produksi lainnya, perlu menjadi prioritas bagi peningkatan produksi dalam negeri. Bantuan dan fasilitasi dari stake holder terkait dibutuhkan agar petani dapat meningkatkan kinerja produksinya. Selain itu, diperlukan juga protokol produksi yang dapat menjamin kualitas dan keamanan pangan yang terbebas dari Covid-19 (Hirawan et.al, 2020).

Pemerintah melalui penyuluh pertanian yang berada di kecamatan berupaya untuk melakukan pendampingan dan fasilitasi dalam pengembangan kualitas pelaku utama dan pelaku usaha pertanian. Peran penyuluhan dalam penyelenggaraan lebih mengarah pada perubahan berencana. Boyle (1981) dalam Nuryanto (2008) mengemukanan bahwa perubahan berencana sebagai kegiatan yang disadari, sengaja dan bersamasama untuk meningkatkan suatu sistem sosial secara operasional, baik itu sistem sosial sendiri, sistem sosial atau sistem kebudayaan melalui pemanfaatan pengetahuan yang tepat. Perubahan yang diinginkan atau berencana harus diidentifikasi dan ditentukan. Perubahan tersebut merupakan deskripsi dari kondisi yang ada antara "what is" dan "what should be", antara yang ada dan yang seharusnya ada.

Perubahan yang direncanakan tersebut membutuhkan peran penyuluh. Levin dalam Nuryanto (2008), penyuluh mempunyai tiga peran utama, yaitu (1) peleburan diri dengan masyarakat sasaran; (2) menggerakkan masyarakat untuk melakukan perubahan berencana; dan (3) memantapkan hubungan sosial dengan masyarakat sasaran. Selanjutnya Lippit dalam Nuryanto (2008), peran penyuluh berkembang sebagai berikut: (1) mengembangkan kebutuhan untuk melakukan perubahan berencana dengan tahapan (a) mengenal masalah dan kebutuhan sistem sosial untuk mengadakan pembaruan; (b) menilai motivasi dan sumberdaya agen pembaharuan; (c) menyeleksi tujuan-tujuan pembaharuan dengan tepat; (d) memilih tipe peran dan bantuan yang akan dimainkan dengan tepat, (2) menggerakkan masyarakat untuk melakukan perubahan dengan melakukan tindakan: (a) membina hubungan baik dan kerjasama terus menerus dengan masyarakat sasaran dan tokoh formal dan tokoh informal; (b) dengan tokoh masyarakat bersama-sama merencanakan upaya perubahan sesuai dengan tahap-tahap pembangunan pertanian jangka panjang; dan (c) mampu menyumbangkan pengetahuan dan keahlian sebagai tenaga professional dalam membangun khalayak sasaran di wilayahnya. Penyuluhan pertanian oleh penyuluh dalam penerapan teknologi baru dapat meningkatkan pendapatan petani. Penyuluhan pertanian tentang sistem tanam baru terbukti dapat meningkatkan pendapatan petani yang signifikan (Saadah et al. 2011). Penyuluh memiliki peranan penting sebagai ujung tombak serta jembatan antara pemerintah dan petani sebagai pelaku utama sehingga dituntut memiliki pengetahuan, informasi yang memadai untuk petani dan kemampuan untuk akses dan tanggap terhadap perkembangan teknologi (Wijaya et al.,2019).

Dalam masa pandemi Covid-19 sekarang ini, peran penting penyuluh pertanian diharapkan terutama dalam menyokong penyediaan bahan pangan. 
Menjamin ketersediaan bahan pokok utamanya beras dan jagung bagi 267 juta masyarakat Indonesia, maka penyuluh pertanian harus bisa memastikan bahwa pertanian jalan terus. Penelitian ini bertujuan untuk mengetahui kinerja penyuluh pertanian selama masa pandemi Covid-19 dan mengetahui faktor-faktor yang mempengaruhi kinerja penyuluh pertanian selama masa pandemi Covid19.

Kinerja penyuluhan yang dimaksud dalam penelitian ini mengacu pada Permentan No. 91 Tahun 2013 tentang Pedoman Evaluasi Kinerja Penyuluh Pertanian, di dalam pedoman ini indikator penilaian kinerja meliputi perencanaan penyuluhan, pelaksanaan penyuluhan, evaluasi dan pelaporan penyuluhan. Indikator yang digunakan dalam penelitian ini adalah perencanaan dan pelaksanaan penyuluhan.

Faktor yang diduga mempengaruhi kinerja penyuluh antara lain karakteristik penyuluh dan faktor eksternal. Karakteristik penyuluh meliputi umur, jenis kelamin, tingkat pendidikan, lama bekerja sebagai penyuluh, dan banyaknya pelatihan di bidang pertanian yang pernah diikuti. Adapun faktor eksternal meliputi jumlah desa binaan, jumlah kelompok tani binaan, sarana prasarana dan kondisi lingkungan kerja.

\section{MATERI DAN METODE}

Penelitian ini merupakan penelitian deskriptif kuantitatif dan berlokasi di Kabupaten Magelang, Jawa Tengah. Waktu pelaksanaan penelitian dilakukan pada bulan Februari 2020 sampai dengan Maret 2020. Teknik penarikan sampel adalah Purposive Sampling dengan kriteria Balai Penyuluhan Pertanian (BPP) Kecamatan yang digunakan Praktik Kerja Lapang mahasiswa Politeknik Pembangunan Pertanian YoyakartaMagelang dengan jumlah 19 kecamatan. Penarikan responden pada setiap kecamatan dilakukan secara accidental sampling yang berjumlah 100 orang. Data yang dikumpulkan dalam penelitian ini dianalisis dengan analisis deskriptif dan analisis model persamaan struktural dengan Partial Least Square menggunakan SEM PLS.

\section{HASIL DAN PEMBAHASAN}

Kabupaten Magelang mempunyai wilayah 1.085,73 $\mathrm{km}^{2}$. Kabupaten Magelang terdiri dari 21 kecamatan dengan jumlah desa sebanyak 372 desa (BPS Magelang, 2020). Penelitian dilakukan dengan responden penyuluh pertanian yang berada di 19 kecamatan, meliputi: Bandongan, Borobudur, Candilmulyo, Grabag, Kajoran, Kaliangkrik, Mertoyudan, Mungkid, Muntilan, Ngluwar, Pakis, Salam, Salaman, Sawangan, Secang, Srumbung, Tegalrejo, Tempuran, dan Windusari.

\section{Karakteristik Responden}

Karakteristik responden dianggap sebagai salah satu unsur penting yang menentukan efektifitas penyuluhan. Karakteristik ini dijelaskan dengan peubah umur, jenis kelamin, pendidikan terakhir, lama menjadi penyuluh pertanian, dan banyaknya pelatihan bidang pertanian yang pernah diikuti. 
Tabel 1. Jumlah responden menurut karaktersitik di lokasi penelitian Tahun 2020

\begin{tabular}{llcr}
\hline & \multicolumn{2}{c}{ Karakteristik Responden } & \multicolumn{2}{c}{ Jumlah } \\
\cline { 2 - 4 } Jenis Kelamin & Laki-laki & 57 & 57,00 \\
\multirow{4}{*}{ Usia } & Perempuan & 43 & 43,00 \\
& $30-39$ & 44 & 44,00 \\
\multirow{5}{*}{ Pendidikan } & $40-49$ & 30 & 30,00 \\
& $50-59$ & 26 & 26,00 \\
& SLTA/sederajat & 31 & 31,00 \\
& Diploma/ sederajat & 11 & 11,00 \\
& Sarjana/ DIV/ sederajat & 57 & 57,00 \\
Lama menjadi penyuluh (tahun) & Pascasarjana & 1 & 1,00 \\
& $<10$ & 18 & 18,00 \\
& $11-19$ & 71 & 71,00 \\
Jumlah pelatihan bidang pertanian & 3 & 3,00 \\
yang pernah diikuti & $20-29$ & 8 & 8,00 \\
& $>30$ & 69 & 69,00 \\
& $<10$ & 25 & 25,00 \\
& $11-19$ & 6 & 6,00 \\
\hline
\end{tabular}

Sumber : Data Terolah, 2020

Dari Tabel 1 di atas, diketahui bahwa sebagian besar responden dalam penelitian ini berjenis kelamin laki-laki, rentang usia antara 30-39 dan mempunyai latar belakang pendidikan sarjana/ sederajat. Sebanyak $57 \%$ penyuluh responden merupakan laki-laki dan sebanyak $43 \%$ sisanya adalah penyuluh responden berjenis kelamin perempuan. Usia reponden, sebanyak $44 \%$ berusia antara $30-39$ tahun, $30 \%$ berusia 40-49 tahun dan sisanya berusia diatas 50 tahun. Hal ini berarti sebagian besar penyuluh pertanian berada pada kondisi produktif dalam bekerja. Selain itu, sebanyak 57\% responden berpendidikan sarjana/sederajat, $31 \%$ berpendidikan sekolah menengah atas/ sederajat, 11 persen merupakan lulusan program diploma, dan hanya 1 penyuluh yang telah mengenyam pendidikan pasca sarjana.

Sebagian besar responden (71\%) telah menjalani pekerjaan sebagai penyuluh selama 11-19 tahun, delapan belas persen merupakan penyuluh yang mempunyai masa kerja sebagai penyuluh kurang dari sepuluh tahun, 3\% penyuluh responden mempunyai masa kerja antara 20-29 tahun, dan sebanyak 8 orang sisanya yang mempunyai masa kerja sebagai penyuluh pertanian diatas 30 tahun. . Selain itu, dari Tabel 1 juga diketahui bahwa sebagian besar responden berada dalam kategori rendah dilihat dari jumlah pelatihan bidang pertanian yang telah diikuti. Sebanyak 69\% responden baru mengikuti pelatihan di bidang pertanian kurang dari 10 kali, 25\% reponden telah mengikuti pelatihan antara 11-19 kali, dan hanya $6 \%$ responden yang telah mengikuti pelatihan bidang pertanian sebanyak 20 kali.

\section{Kinerja Penyuluh Pertanian}

Sejak dikeluarkannya Surat Edaran Bupati Magelang Nomor: 360/084/46/2020 tanggal 22 Maret 2020 tentang Penegasan Pencegahan dan Penanganan Covid-19 di Kabupaten Magelang, maka kegiatan penyuluhan 
pertanian juga mengalami penyesuaian. Kinerja penyuluhan pertanian diukur dengan perencaan penyuluhan pertanian dan pelaksanaan kegiatan penyuluhan. Perencanaan penyuluhan pertanian dapat dilihat melalui parameter yang meliputi pembuatan data potensi wilayah dan agro ekosistem, pengawalan dan pendampingan penyusunan Rencana Definitif Kebutuhan Kelompok (RDKK), penyusunan programa penyuluhan desa dan kecamatan, dan pembuatan Rencana Kerja Tahunan Penyuluh
Pertanian (RKTPP). Adapun indikator pelaksanaan penyuluhan dapat diukur melalui pelaksanaan desiminasi materi penyuluhan sesuai kebutuhan petani, pelaksanaan metode penyuluhan pertanian di wilayah binaan, pelaksanaan peningkatan kapasitas petani terhadap akses informasi dalam mengembangkan usahatani, penumbuhan kelembagaan petani, penumbuhan kelembagaan ekonomi petani, peningkatan produksi komoditas $\begin{array}{lll}\text { unggulan di WKPP. } & \end{array}$

Tabel 2. Kinerja Penyuluh Pertanian

\begin{tabular}{llrr}
\hline \multicolumn{2}{c}{ Kinerja Penyuluh Pertanian } & \multicolumn{2}{c}{ Jumlah } \\
\cline { 3 - 4 } a. Perencanaan penyuluhan & & Orang & $\%$ \\
Penyusunan IPW & Kadang-kadang & 5 & 5.00 \\
& Selalu & 95 & 95.00 \\
Pendampingan penyusunan & Kadang-kadang & 3 & 3.00 \\
RDKK & Selalu & 97 & 97.00 \\
Penyusunan programa & Kadang-kadang & 4 & 4.00 \\
& Selalu & 96 & 96.00 \\
Penyusunan RKTPP & Kadang-kadang & & \\
& Selalu & 100 & 100.00 \\
b. Pelaksanaan penyuluhan & & & \\
Diseminasi materi & Kadang-kadang & 1 & 1.00 \\
& Selalu & 99 & 99.00 \\
Pelaksanaan metode penyuluhan & Kadang-kadang & 4 & 4.00 \\
& Selalu & 96 & 96.00 \\
Peningkatan kapasitas petani & Kadang-kadang & 6 & 6.00 \\
& Selalu & 94 & 94.00 \\
Penumbuhan kelembagaan petani & Kadang-kadang & 31 & 41.00 \\
& Selalu & 69 & 59.00 \\
Penumbuhan kelembagaan & Kadang-kadang & 30 & 40.00 \\
ekonomi petani & Selalu & 70 & 60.00 \\
Peningkatan produksi & Kadang-kadang & 3 & 3.00 \\
& Selalu & 97 & 97.00 \\
\hline
\end{tabular}

Sumber : Data Terolah, 2020

Hasil analisis pada Tabel 2 menunjukkan bahwa pada indikator perencanaan penyuluhan, sebagian besar responden selalu melakukan kegiatan penyusunan data potensi wilayah dan agroekosistem (95\%), pengawalan dan pendampingan penyusunan RDKK (97\%), penyusunan 
programa desa dan kecamatan (96\%), serta malakukan penyusunak RKTPP (100\%). Untuk indikator pelaksanaan penyuluhan, sebagian besar responden selalu melaksanakan kegiatan diseminasi materi penyuluhan (99\%), pelaksanaan metode kunjungan lapangan (96\%), peningkatan kapasitas petani (94\%), penumbuhan kelembagaan petani (69\%), penumbuhan kelembagaan ekonomi petani $(70 \%)$, dan upaya peningkatan produksi komoditas unggulan di WKPP (97\%). Walaupun demikian, terdapat beberapa perubahan dalam pelaksanaan penyuluhan kepada sasaran selama masa pandemi Covid19. Perubahan kegiatan tersebut dapat dilihat pada Tabel 3 berikut.

Tabel 3 Perubahan Kegiatan Pembinaan Selama Masa Pandemi Covid-19

\begin{tabular}{llrr}
\hline \multicolumn{2}{c}{$\begin{array}{c}\text { Perubahan Kegiatan Pembinaan Selama Masa Pandemi } \\
\text { Covid-19 }\end{array}$} & & \multicolumn{2}{c}{ Jumlah } \\
\cline { 3 - 4 } & Yrang & $\%$ \\
\hline Perubahan frekuensi kunjungan ke sasaran & Ya & 90 & 90.00 \\
Perubahan jumlah materi pembinaan & Tidak & 10 & 10.00 \\
& Ya & 65 & 65.00 \\
Perubahan metode pembinaan & Tidak & 35 & 35.00 \\
& Ya & 94 & 94.00 \\
& Tidak & 6 & 6.00 \\
\hline
\end{tabular}

Sumber : Data Terolah, 2020

Hasil analisa data, menunjukkan bahwa selama masa pandemik Covid19, terjadi perubahan kegiatan pembinaan kepada sasaran. Tabel 3 menunjukkan bahwa ada perubahan kegiatan dalam pembinaan kepada sasaran selama masa pandemik Covid19. Sebanyak $90 \%$ responden mengurangi frekuensi kunjungan pembinaan ke petani/poktan/ gapoktan. Hanya $10 \%$ responden yang tidak merubah frekuensi kunjungan ke sasaran. Senada dengan hal itu, materi pembinaan kepada sasaran juga mengalami perubahan. Sebanyak $65 \%$ responden mengurangi jumlah materi pembinaannya dan $35 \%$ responden tidak mengubah jumlah materi pembinaannya. Metode pembinaan juga mengalami perubahan, sebanyak $94 \%$ responden mengubah metode pembinaannya. Metode anjangsana, pertemuan tatap muka, ceramah, dan demonstrasi tidak dapat dilakukan karena adanya pembatasan kegiatan yang melibatkan banyak orang. Metode yang digunakan oleh penyuluh pertanian dalam masa pandemi ini dengan pemanfaatan teknologi informasi dan komunikasi. Kegiatan penyuluhan dilakukan secara daring/ online, menggunakan aplikasi whatsapp grup, atau melalui telepon, layanan pesan pendek/ short message service (SMS), maupun media sosial. Selain itu, apabila dilakukan kunjungan secara tatap muka, penyuluhan dilakukan melalui perorangan atau perwakilan dari poktan. Pemanfaatan perangkat teknologi informasi dan komunikasi dapat digunakan sebagai media untuk kegiatan penyuluhan pertanian dengan didukung oleh komunikasi personal (Wibowo, 2015). Penelitian lain yang senada dilakukan oleh Khasanah et al., (2020), bahwa kegiatan penyuluhan dan pelatihan dalam masa pandemik Covid19 dapat dilakukan secara online dengan memanfaatkan platform teknologi informasi dan komunikasi, 
seperti whatsapp, google meet, dan lainnya. Pemanfaatan teknologi informasi melalui pemanfaatan media online dapat digunakan sebagai sarana untuk bertukar informasi dan diskusi antara petani, penyuluh pertanian dan beberapa stakeholder terkait (Ardelia et.al., 2020).

\section{Faktor Eksternal}

Setiap penyuluh pertanian berada di Balai Penyuluhan Pertanian di kecamatan mempunyai desa/kelurahan yang menjadi binaannya. Untuk menyelenggarakan kegiatan penyuluhan secara efektif dan efisien, aktifitas penyuluh pertanian dibatasi pada satu wilayah kerja/ kawasan yang disebut Wilayah Kerja Penyuluh Pertanian (WKPP) yang menjadi tanggung jawab binaan setiap penyuluh. Wilayah ini dapat berupa satuan wilayah desa/ kelurahan. Idealnya setiap satu oarng penyuluh akan membina satu desa/kelurahan. Akan tetapi karena keterbatasan jumlah penyuluh pertanian, dimungkinkan satu penyuluh membina lebih dari satu desa/ kelurahan.

Tabel 4. Jumlah Desa dan Kelompok Tani Binaan Penyuluh Pertanian

\begin{tabular}{lccc}
\hline \multicolumn{2}{c}{$\begin{array}{c}\text { Jumlah Desa dan Kelompok Tani Binaan Penyuluh } \\
\text { Pertanian }\end{array}$} & \multicolumn{2}{c}{ Jumlah } \\
\cline { 3 - 4 } Jumlah desa binaan penyuluh & 1 & orang & $\%$ \\
pertanian dalam WKPP & 2 & 60 & 27.00 \\
& 3 & 11 & 60.00 \\
& 4 & 1 & 11.00 \\
Jumlah kelompok tani binaan & 5 & 1 & 1.00 \\
penyuluh pertanian & $1-10$ & 17 & 17,00 \\
& $11-19$ & 61 & 61,00 \\
& $20-29$ & 20 & 20,00 \\
& $\geq 30$ & 2 & 2,00 \\
\hline
\end{tabular}

Sumber : Data Terolah, 2020

Sebagian besar $(60 \%)$ penyuluh pertanian mempunyai wilayah binaan yang meliputi 2 desa/kelurahan, $27 \%$ penyuluh pertanian membina 1 desa/kelurahan. $11 \%$ penyuluh pertanian membina 3 desa, dan hanya 2 orang $(2 \%)$ yang membina lebih dari 3 desa. Hal ini menunjukkan bahwa untuk menuju ke dalam kondisi ideal satu desa satu penyuluh masih membutuhkan penyuluh pertanian.

Penyuluh pertanian kemudian membagi WKPP menjadi delapan sampai dengan enam belas wilayah kelompok (wikel). Satu wilayah kelompok merupakan wilayah usaha tani satu kelompok tani (poktan). Dengan demikian, idealnya satu penyuluh pertanian akan membina 16 poktan. Data yang ditunjukkan Tabel 4 menunjukkan bahwa sebagian besar penyuluh $(61 \%)$ membina $11-19$ poktan, sebanyak 20 persen penyuluh membina antara 20-29 poktan, 17 persen penyuluh menbina kurang dari sepuluh poktan, dan 2 penyuluh yang membina lebih dari 30 poktan. 
Tabel 5. Penggunaan Sarana dan Prasarana dalam Melakukan Penyuluhan

\begin{tabular}{llrr}
\hline \multirow{2}{*}{ Penggunaan Sarana dan Prasarana dalam Melakukan } & \multicolumn{3}{c}{ Jumlah } \\
\cline { 3 - 4 } Penyuluhan & & \multicolumn{2}{c}{ Orang } \\
\hline Sepeda motor & Ya & 97 & 97.00 \\
& Tidak & 3 & 3.00 \\
Komputer/ laptop & Ya & 86 & 86.00 \\
& Tidak & 14 & 14.00 \\
Telepon genggam & Ya & 99 & 99.00 \\
& Tidak & 1 & 1.00 \\
Layanan Internet & Ya & 97 & 97.00 \\
& Tidak & 3 & 3.00 \\
LCD/ proyektor & Ya & 79 & 79.00 \\
& Tidak & 21 & 21.00 \\
\hline
\end{tabular}

Sumber : Data Terolah, 2020

Keberhasilan penyelenggaraan penyuluhan tidak terlepas dari dukungan ketersediaan sarana dan prasarana yang memadai, sehingga keberadaannya menjadi penting di setiap tingkatan kelembagaan. Pemerintah melalui Kementerian Pertanian telah menerbitkan Peraturan Menteri Pertanian Nomor 51 Tahun 2009 tentang Pedoman Standar Minimal dan Pemanfaatan Sarana dan Prasaranan Penyuluhan Pertanian meningkatkan kapasitas kelembagaan dalam penyelenggaraan penyuluhan pertanian yang efektif dan efisien, diperlukan sarana dan prasarana yang memadai. Beberapa sarana dan prasarana yang menjadi standar minimal menjadi fokus yang mendukung variabel. Dari Tabel 5 di atas, dapat diketahui bahwa dalam melakukan pembinaan kepada petani/ poktan/ gabungan kelompok tani di masa pandemik Covid-19 ini, sebagian besar responden $(97 \%)$ menggunakan sepeda motor untuk mendukung operasional kegiatan penyuluhan, sedangkan 3 persen responden tidak menggunakan sepeda motor dalam menjalankan tugasnya. Hal serupa juga dijumpai pada pemanfaatan sarana dan prasarana yang lain, yaitu pada pemanfaatan computer/laptop, telepon genggam, layanan internet, dan LCD/proyektor. Sebagian besar responden menggunakan alat-alat tersebut di atas untuk memudahkan pembinaan dan pendampingan kepada petani/ poktan/ gapoktan. Selain sarana dan prasarana tersebut di atas, beberapa penyuluh juga menggunakan beberapa alat lain untuk mendukung kegiataannya, seperti $\mathrm{pH}$ meter, peta singkap, soundsystem, leaflet, brosur, alat peraga, kamera, peta singkap, alat pelindung diri (APD), dan lainnya. 
Tabel 6. Kondisi Lingkungan Wilayah Kerja

\begin{tabular}{llrr}
\hline \multicolumn{2}{c}{ Kondisi Lingkungan Wilayah Kerja } & \multicolumn{2}{c}{ Jumlah } \\
\cline { 3 - 4 } & & Orang & $\%$ \\
\hline Jarak desa binaan dengan tempat & Dekat & 74 & 74.00 \\
tinggal & Sedang & 24 & 24.00 \\
& Jauh & 2 & 2.00 \\
Persepsi terhadap jarak desa binaan & Mempengaruhi & 60 & 60.00 \\
dengan tempat tinggal dengan kinerja & Tidak Mempengaruhi & 40 & 40.00 \\
Desa/kelurahan wilayah binaan & Ya & 86 & 86.00 \\
mengalami pembatasan & Tidak & 14 & 14.00 \\
lokal/lockdown & & 68 & 68.00 \\
Persepsi terhadap status desa binaan & Berpengaruh & 11 & 11.00 \\
"lockdown" & Kurang berpengaruh & 21 & 21.00 \\
& Tidak berpengaruh & 94 & 94.00 \\
Perbedaan melakukan pembinaan & Ya & 6 & 6.00 \\
selama Covid-19 & Tidak & & \\
\hline
\end{tabular}

Sumber : Data Terolah, 2020

Hasil data yang dikumpulkan menunjukkan bahwa sebagian besar responden mempunyai jarak yang dekat antara desa binaan dengan tempat tinggalnya. Jarak desa binaan dengan tempat tinggal penyuluh dikalsifikasikan menjadi 3, yaitu dekat (antara 0,1 15,66 km), sedang (antara 15,67 $38,66 \mathrm{~km}$ ), dan jauh (lebih dari 38,67 $\mathrm{km})$. Sebanyak $74 \%$ responden masuk dalam kategori dekat, 24\% kategori sedang, dan $2 \%$ responden termasuk dalam kategori jauh. Sebanyak $60 \%$ responden berpendapat bahwa jarak antara desa binaan berpengaruh terhadap kinerja, sedangkan $40 \%$ menyatakan bahwa hal tersebut tidak mempengaruhi kinerja mereka selama masa pandemik Covid-19 ini. Tabel 6 menunjukkan bahwa sebagian besar desa/ kelurahan (86\%) binaan penyuluh mengalami pembatasan lokal/ lockdown dalam upaya pencegahan penyebaran Covid-19. Sebagian besar responden $(68 \%)$ berpendapat bahwa status desa binaan yang mengalami pembatasan lokal/ lockdown mempengaruhi kinerja mereka. Sedangkan 11 persen responden menganggap hal tersebut kurang berpengaruh terhadap kinerja, dan sisanya sebanyak 21 persen menggap kondisi pembatasan lokal pada desa binaan tidak berpengaruh terhadap kinerja mereka. Dampak adanya covid-19 ini merubah pembinaan penyuluh kepada petani/ poktan/ gapoktan. Sebanyak 94 persen responden mengatakan bahwa terjadi perbedaan dalam melakukan pembinaan kepada petani/ poktan/ gapoktan.

\section{Faktor yang Berpengaruh terhadap Kinerja Penyuluhan di Masa Pandemi Covid-19}

Berdasarkan Gambar 1, hasil analisa SEM, menunjukan bahwa kinerja penyuluhan pertanian di masa pandemi Covid-19 dipengaruhi secara nyata oleh karakteristik penyuluh (X1) dan faktor eksternal (X2). Pengaruh karakteristik penyuluh terhadap kinerja penyuluh pertanian sebesar 0,29 dan pengaruh faktor eksternal terhadap kinerja penyuluh sebesar 0,02 . Indikator dominan dari karakteristik penyuluh 
pertanian yang mempunyai pengaruh tersebut terutama usia penyuluh $(0,29)$, tingkat pendidikan formal penyuluh $(0,47)$ dan jumlah pelatihan di bidang pertanian yang telah diikuti oleh penyuluh $(0,26)$. Indikator karakteristik berdasarkan jenis kelamin dan lama bekerja sebagai penyuluh pertanian tidak termasuk dalam model, karena tidak memberikan pengaruh nyata terhadap kinerja penyuluh pertanian. Kedua indikator ini dikeluarkan dari model. Indikator usia berpengaruh terhadap kinerja sejalan dengan kajian Lodismith dan Robert (2010) yang menyatakan bahwa usia mempengaruhi pengalaman dalam mencari kesuksesan dalam pekerjaan. Sedangkan tingkat pendidikan terbukti nyata berpengaruh terhadap kinerja penyuluh. $\mathrm{Hal}$ ini selaras dengan hasil penelitian Subagio (2008), Fatchiya (2010), dan Yunita (2011), bahwa pendidikan mempunyai pengaruh nyata pada kemampuan seseorang dalam menjalankan suatu pekerjaan. Senada dengan hasil penelitian Haryanto (2018), penyuluh dengan tingkat pendidikan yang cukup tinggi mampu mengakses sumber informasi teknologi dan tingkat kosmopolitan yang baik untuk memperkuat jejaring yang bermanfaat bagi petani.

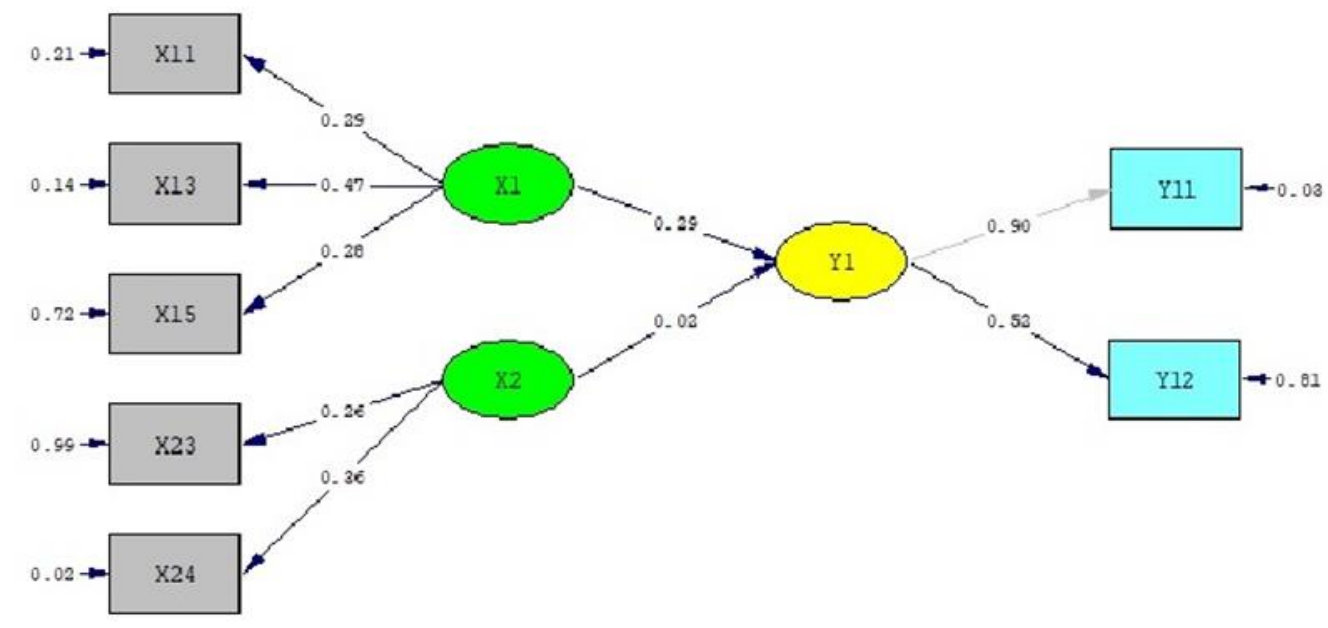

Gambar 1. Model struktural faktor yang berpengaruh terhadap kinerja penyuluh pertanian

Dari Gambar 1 juga dapat diketahui bahwa indikator faktor eksternal yang berpengaruh terhadap kinerja penyuluh adalah ketersediaan sarana prasarana $(0,26)$. Hal ini sesuai dengan penelitian Pramono (2012), yang menyebutkan bahwa sarana dan prasarana yang baik dengan didukung oleh kompetenasi sumberdaya manusia berpengaruh langsung terhadap kinerja seseorang. Indikator faktor eksternal yang lain yang berpengaruh adalah kondisi wilayah kerja penyuluh $(0,26)$. Hasil ini memperkuat kajian yang telah dilakukan oleh Budianto et al., (2015); dan Hartono et al., (2018) yang menyebutkan bahwa kondisi lingkungan kerja bersama-sama dengan motivasi dan kedisiplinan seseorang berpengaruh positif terhadap kinerja. Indikator jumlah kelompok tani dan desa/ kelurahan binaan tidak 
memberikan pengaruh nyata terhadap kinerja penyuluh pertanian, sehingga dikeluarkan dari model.

\section{Simpulan}

\section{KESIMPULAN}

Hasil analisa terhadap kinerja penyuluhan yang diukur melalui parameter perencanaan penyuluhan dan pelaksanaan penyuluhan menunjukkan bahwa sebagian besar responden tetap melaksanakan perencanaan penyuluhan dan pelaksanaan penyuluhan selama masa pandemi Covid-19. Hasil penelitian juga menunjukkan bahwa pembinaan oleh penyuluh pertanian kepada petani/ poktan/ gapoktan selama masa pandemi Covid-19 ini mengalami perubahan. Perubahan terjadi pada jumlah kunjungan penyuluh pertanian ke sasaran, jumlah materi pembinaan yang diberikan, dan metode penyuluhan.

$$
\text { Faktor-faktor }
$$

yang mempengaruhi kinerja penyuluh pertanian selama masa pandemi Covid19 adalah karakteristik penyuluh pertanian dan faktor eksternal. Indikator karakteristik penyuluh yang berpengaruh terhadap kinerja penyuluhan adalah usia penyuluh, tingkat pendidikan penyuluh, dan banyaknya pelatihan di bidang pertanian. Sedangkan indikator faktor eksternal yang berpengaruh terhadap kinerja penyuluhan adalah sarana dan prasarana penunjang kegiatan penyuluhan dan kondisi lingkungan tempat kerja penyuluh pertanian.

\section{Saran}

Hal yang perlu diperhatikan dalam meningkatkan kinerja penyuluh pertanian selama masa pandemi Covid19 antara lain peningkatan kemampuan/ kompetensi sumberdaya manusia di bidang pemanfaatan teknologi informasi dan komunikasi, baik penyuluh pertanian dan sasaran penyuluhan;

Pemanfaatan teknologi informasi dan komunikasi sebagai media penyuluhan pertanian akan lebih efektif apabila diikuti oleh komunikasi personal secara tatap muka langsung dengan melibatkan jumlah peserta terbatas dan penerapan protocol kesehatan.

\section{DAFTAR PUSTAKA}

Ardelia, R, Oeng Anwarudin, Nazaruddin. 2020. Akses teknologi informasi melalui media elektronik pada petani KRPL. Jurnal Triton. 11 (1):24-36

Budianto, AAT, Amelia Katini. 2015. Pengaruh Lingkungan Kerja Terhadap kinerja Pegawai Pada PT Perusahaan Gas Negara (Persero) Tbk SBU Distribusi Wilayah I Jakarta. Jurnal IImu Prodi Manajemen Universitas Pamulang. 3(1):100-124

[BPS Kabupaten Magelang] Badan Pusat Statistik Kabupaten Magelang. 2020. Kabupaten Magelang Dalam Angka. Magelang (ID): Badan Pusat Statistik Kabupaten Magelang

[BPS] Badan Pusat Statistik. 2020. Pertumbuhan Ekonomi Indonesia Triwulan II-2020. No 64/08/Th.XXIII 5 Agustus 2020. Jakarta (ID): Badan Pusat Statistik

Fatchiya A. 2010. Pola Pengembangan Kapasitas Pembudidaya Ikan Kolam Air Tawar di Provinsi Jawa Barat. [Disertasi]. Bogor (ID): Institut Pertanian Bogor

Hartanto, Susi Hendriani, Yusni Maulida. 2018. Analisis Pengaruh Kondisi Kerja, Motivasi Kerja, dan Disiplin Kerja Terhadap Kinerja Pegawai Kantor Wilayah 
Direktorat Jenderal Kekayaan Negara Riau, Sumatera Barat, dan Kepulauan Riau. Jurnal Tepak Manajemen Bisnis. X(2): 226-241

Haryanto, Yoyon. 2018. Penguatan Kapasitas dan Kemandirian Tokoh Petani Maju sebagai Penyuluh Swadaya. [Disertasi]. Bogor (ID): Institut Pertanian Bogor

Hirawan, Fajar B dan Akita A Verselita. 2020. Kebijakan Pangan di Masa Pandemi Covid-19. CSIS Commentaries DMRU-048-ID

Khasanah, FN, Herlawati, Seta Samsiana, Rahmadya TH, Anita $\mathrm{S}$, Irwan raharja, Maemunah, Benrahman. 2020. Pemanfaatan media sosial dan ecommerce sebagai media pemasaran dalam mendukung peluang usaha mandiri pada masa pandemi Covid-19. Jurnal Sains Teknologi dalam

Pemberdayaan Masyarakat. 1(1): 51-62

[Kementan] Kementerian Pertanian. 2014. Strategi Induk Pembangunan Pertanian 20152045: $\quad$ Pertanian-Bioindustri Berkelanjutan. Jakarta (ID): Kementerian Pertanian

Lodismith J. Roberts W. 2010. Getting to Know Me: Social Role Experiences and Age Differences in Self-Concept Clarity During Adulthood. Journal of Personality. 78(5): $1384-1410$

Maryani,A, Yoyon Haryanto, Oeng Anwarudin. 2017. Strategy of agricultural extension to improve participation of the farmers in special effort in increasing rice production. International Journal of Sciences.36 (4): 163-174

Nuryanto BG. 2008. Kompetensi penyuluh dalam pembangunan pertanian di Provinsi Jawa Barat [disertasi]. Bogor (ID): Institut Pertanian Bogor

Pramono, Harry. 2012. Pengaruh Sistem Pembinaan, Sarana dan Prasarana dan Pendidikan Latihan terhadap Kompetensi Kinerja Guru Pendidikan Jasmani Sekolah Dasar di Kabupaten Semarang. Jurnal Penelitian Pendidikan. 29(1):7-16

Saadah, Sulili A, Deserama RB. 2011. Peranan penyuluhan pertanian terhadap pendapatan petani yang menerapkan sistem tanam jajar legowo. Jurnal Agrisistem. Desember 7 (2): 91-94

Subagio H. 2008. Peranan kapasitas petani dalam mewujudkan keberhasilan usaha tani: Kasus Petani Sayuran dan Padi di Kabupaten Malang dan Pasuruan Propinsi Jawa Timur. [Disertasi]. Bogor (ID): Institut Pertanian Bogor

Sumardjo, Mulyandari RSH, Prawiranegara D, Darmawan L. 2012. Dissemination of agricultural innovation system based on information technology to increase the vegetable farmer empowerment. Prosiding Seminar Hasil Penelitian IPB 2012

Wibowo, Haris T, Djuara P Lubis, Resfa Fitri. 2015. Layanan Pesan Pendek untuk Pembangunan Pertanian di Kabupaten Karawang. Jurnal Komunikasi Pembangunan. 13(2):72-84

Wijaya AS, Sarwoprasodjo S, Febrina D. 2019. Cyber extension: use of media and information search strategy in the agriculture of Agricultural Bogor District. Jurnal Komunikasi Pembangunan. 17(2), 117-121

Yunita. 2012. Strategi Peningkatan Kapasitas Rumah Tangga Petani 
Padi Sawah Lebak Menuju Ketahanan Pangan Rumah Tangga (Kasus di Kabupaten
Ogan Ilir dan Ogan Komelir llir. [Disertasi]. Bogor (ID): Institut Pertanian Bogor 